African Crop Science Journal by African Crop Science Society is licensed under a Creative Commons Attribution 3.0 Uganda License. Based on a work at www.ajol.info/ and www.bioline.org.br/cs DOI: http://dx.doi.org/10.4314/acsj.v26i2.11

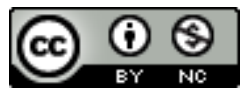

\title{
DIVERSITY LEVEL OF GENOMIC MICROSATELLITE AMONG CULTIVATED GENOTYPES OF Digitaria SPECIES IN NIGERIA
}

\author{
D.A. ANIMASAUN ${ }^{1}$, K.F. AWUJOOLA ${ }^{1}$, S. OYEDEJI ${ }^{1}$, J.A. MORAKINYO ${ }^{1}$ and R. KRISHNAMURTHY ${ }^{1,2}$ \\ ${ }^{1}$ Department of Plant Biology, Faculty of Life Sciences, University of Ilorin, P.M.B. 1515, Ilorin, \\ Kwara State, Nigeria \\ ${ }^{2}$ C.G. Bhakta Institute of Biotechnology, Uka Tarsadia University, Bardoli, Gujarat, India \\ Correspondence author: biostanleydayor@yahoo.com.au, animasaun.ad@unilorin.edu.ng
}

(Received 2 November, 2017; accepted 7 May, 2018)

\begin{abstract}
Acha (Digitaria exilis Kipps. and D. iburua Stapf.) are valuable indigenous food crops in West Africa. Despite several economic potentials of this crop, little or no attention is paid to its germplasm evaluation and improvement. In this study, we assessed genetic diversity and relationship among genotypes of cultivated acha in Nigeria, using Inter-Simple Sequence Repeat (ISSR) markers for the first time. Genomic DNA were extracted from the genotypes and we performed fragment amplification by Polymerase Chain Reaction (PCR). A total of 95 loci consisting of 790 bands were amplified by 13 ISSR primers, out of which $53.37 \%$ were polymorphic. Loci amplification per primer ranged from 5-10, with an average of 7.30 loci per primer. Eight of the primers had above 50\% polymorphism. Cluster analysis separated the genotypes into two major groups; a group consisting of two $D$. exilis genotypes and the other comprising a mixture of genotypes. The D. exilis in the latter group were distant members and was only similar at 0.72 similarity index. The polymorphism we obtained in the present study showed that the ISSR markers are effective for assessment of genetic diversity of the genotypes. Clustering of D. exilis and D. iburua together suggests a common progenitor but could have been separated by geographical isolation mechanism.
\end{abstract}

Key Words: Digitaria exilis, D. iburura, genetic diversity, ISSR markers, orphan crops

\section{RÉSUMÉ}

Les fonios (Digitaria exilis Kipps. et D. iburua Stapf) sont des cultures alimentaires très importantes en Afrique de l'Ouest. Malgré les différentes potentialités économiques de cette culture, très peu ou aucune attention n'est portée sur l'évaluation et l'amélioration de son germplasm. Dans cette étude, nous avions évalué la diversité génétique et la relation entre les génotypes cultivés du fonio au Nigéria, en utilisant les markers Inter-Simple SequenceRepeat (IISSR) pour la première fois. Les ADN génomiques étaient extraits des génotypes et nous avions utilisé la technologie de Réaction en Chaîne de la Polymérase (PCR). Un total de 95 loci contenant 790 bands étaient amplifiées par 13 amorces d'ISSR, sur lesquelles 53,37\% étaient polymorphiques. L'amplification des loci par amorces variait de 5 à 10, avec une moyenne de 7.30 loci per amorce. Huit des amorces ont plus de $50 \%$ de polymorphisme. L'analyse typologique a séparé les génotypes en deux grands groupes; un groupe comportant deux génotypes de $D$. exilis et les autres comprennent un mélange de génotypes. Les $D$. exilis dans le dernier groupe étaient membres distants et étaient le seul similaire à 0,72 d'indice de similarité. Le polymorphisme que nous avons obtenu dans cette étude a montré que les markers ISSR sont efficaces pour l'évaluation de la diversité génétique des génotypes. Le regroupement de $D$. exilis et $D$. iburua ensemble suggère un parent commun mais pourrait être séparé par le mécanisme d'isolement géographique.

Mots Clés: Digitariaexilis, D. iburura, diversitégenetic, cultures orphelines, markers ISSR 


\section{INTRODUCTION}

Digitaria exilis (Kipps) Stapf. and D. iburua Stapf. (acha) also called fonio millets represent an integral component of millet biodiversity in the savannah zone of West-Africa. Acha belong to family Poaceae and genus Digitaria. The genus comprises of about 230 grasses, with a wide geographic distribution in the tropics and subtropics (Clayton and Renvoize, 1986). Acha are the most economically important crops in this genus. Although, a number of wild species occur as forage grasses, $D$. iburua (black acha) and D. exilis (white acha) are used for food in West and other parts of Africa (Adoukonou-Sagbadja et al., 2006).

Acha is native to West-Africa where it is cultivated in the savannah regions, but the species $D$. iburua is currently limited in areas of cultivation. It is only found in Northern Nigeria, Togo and Benin, which represent a relic of formerly wider cultivation (Porteres, 1946; Haq and Ogbe, 1995). Unlike D. iburua, $D$. exilis has wider areas of cultivation and had been reportedly cultivated in Dominican Republic (Morales-Payan et al., 2002). Acha meals are well appreciated for its taste and easy digestibility in many tribal areas of Guinea, Mali, Togo and Nigeria. The protein composition is rich in methionine and cystine, the two vital amino-acids usually deficient in major cereals (Vietmeyer et al., 1996).

Despite the importance of this crop to traditional agriculture in West Africa, research efforts to improve the crop is still grossly inadequate. Consequently, the crop remain primitive facing diverse agronomical problems which, contribute notably to grain yield lost (Maji et al., 2003). Traditionally, local farmers distinguish three groups based on the growth cycle: precocious, intermediate and late maturing types. The first insight into the characterisation of acha genetic diversity was based on morph-botanical characteristics (Porteres, 1976). However, the study did not include $D$. iburua due to its restricted cultivation areas. There are other reports on acha characterisation using agronomic traits (Adoukonou-Sagbadja et al., 2006; Dachi and Gana, 2008).

Diversity analysis based on morphological traits may be inflated and unrealistic, due to environmental influence. Since acha exhibit some level of isomorphism and is difficult to distinguish morphologically during the vegetative growth stage, molecular characterisation of the available germplasm is imperative. This will facilitate the use of genetic resources and estimation of genetic relatedness among the genotypes faster than the conventional methods (Semagn et al., 2006). Thus, efficiency of genetic gain by selection can be improved if the patterns of genetic diversity within a population of breeding lines are known. This could be of significant importance in varietal identification, proper purity maintenance and implementation of germplasm conservation. Attempts using RAPD markers to assess the molecular variability of acha have been reported, but it involved few accessions from geographically restricted areas of Togo and Nigeria (Hilu et al., 1997).

There is still a wide knowledge gap of genetic diversity and molecular characterisation of the West Africa acha genotypes. Furthermore, genotypes from Nigeria were not included in the previous molecular characterisation studies. The objective of this study was to assess the genetic diversity in the germplasm of two cultivated species of acha $(D$. exilis and $D$ iburua) in Nigeria, using microsatellite (ISSR) markers.

\section{MATERIALS AND METHODS}

Plant material. Seeds of eleven genotypes of two cultivated species of acha (D. exilis and $D$. iburua) were collected from different sources in Nigeria (Table 1). The seeds were grown in a screen house to raise young plants for the molecular characterisation. Two weeks after germination, young unfolding leaves of 
TABLE 1. Genotype name, common name, and source of D. exilis and D. iburua used for the study

\begin{tabular}{llll}
\hline Genotype & Name & Common name & Source $^{\dagger}$ \\
\hline Gwabi & D. iburua & Black acha & NCRI \\
Kereep & D. exilis & White acha & NCRI \\
Agyong & D. exilis & White acha & NCRI \\
Gopanto & D. iburua & Black acha & NCRI \\
Ndai & D. exilis & White acha & NCRI \\
Nopiya & D. iburua & Black acha & NCRI \\
Bauchi & D. iburua & Black acha & Field \\
NGB00629 & D. exilis & White acha & NACGRAB \\
Niger & D. iburua & Black acha & Market \\
Kebbi & D. exilis & Black acha & Field \\
Kebbi-2 & D. iburua & Black acha & Field \\
\hline
\end{tabular}

${ }^{\top} \mathrm{NCRI}=$ National Cereal Research Institute, Badeggi Niger state Nigeria NACGRAB = National Centre for Genetic Resources and Biotechnology, Ibadan, Nigeria

each genotype were harvested into separate labelled sample bottles for DNA isolation.

DNA isolation and polymerase chain reaction. Genomic DNA was isolated from $100 \mathrm{mg}$ of the leaf sample using Zymo Plant Mini Kit (Zymo Research, USA). The quality of the DNA was checked on $0.8 \%$ agarose gels and the DNA concentrations estimated using a Nanodrop 8000 spectrophotometer (Nanodrop Technologies, USA). A total of 20 Inter-Simple Sequence Repeat (ISSR) primers were initially used for the Polymerase Chain Reaction (PCR). The final reaction volume was $20 \mu \mathrm{l}$ in in thin wall PCR tube (Axygen; USA). Each reaction mixture consisted of $1.0 \mu \mathrm{l}$ (50 ng) of gDNA, $1.0 \mu \mathrm{l}$ of primer $\left(10 \mathrm{pmol} \mathrm{ml}^{-1}\right)$, $10.5 \mu \mathrm{l}$ of $1 \mathrm{X}$ PCR mix $(3 \mathrm{mM} \mathrm{MgCl}, 0.2$ mM dNTPs, one unit of Taq DNA Polymerase (Fermentas, Life Sciences) and 7.5 $\mu \mathrm{l}$ nuclease free water. The PCR was performed on Thermal cycler (Applied Biosystems, USA) following the PCR conditions of Animasaun et al. (2015). The PCR products and loading dye were electrophoresed on $1.5 \%$ agarose gel stained with ethidium bromide using $1 \mathrm{X}$ TAE buffer. Fragment sizes of the amplified products were anticipated from the gel by comparison with standard molecular weight marker (Thermofisher, USA). The amplified product was visualised as a single compact band under UV light and documented by gel documentation system (SIGMA-3-16KL).

Data analysis. Reproducible and clear bands were scored as 1 for presence and 0 for absence across the lanes in reference to the standard marker. The data were subsequently used to construct a dendrogram using the unweighted pair group method of arithmetic averages (UPGMA). All the computations were carried out using the NTSYpc (Numerical Taxonomy and Multivariate Analysis System) Software Version 2.

\section{RESULTS}

The concentrations of genomic DNA extracted from the genotypes of acha ranged from 123.81-186.03 $\mathrm{g} \mathrm{\mu l}^{-1}$, the OD (Optical Density) at $260-280 \mathrm{~nm}$ was between 1.51 and 1.72 . Out of the twenty ISSR primers tested, thirteen ISSR markers produced remarkable and reproducible fragments. A total of 95 bands were generated by 13 primers with average of 7.30 loci per primer (Table 2). About 53\% of the amplified loci were polymorphic and $46.6 \%$ were monomorphic bands. Figure 1 showed 
TABLE 2. Amplification and polymorphism pattern of ISSSR markers used in the diversity study of accessions of Digitaria spp.

\begin{tabular}{lllcrcrc}
\hline SN & $\begin{array}{c}\text { Marker } \\
\text { code }\end{array}$ & Sequence (5'- 3') & TNA & TNL & NML & NPL & P (\%) \\
\hline 1 & ISSR1 & GAGAGAGAGAGACC & 51 & 6 & 3 & 3 & 50.00 \\
2 & ISSR2 & CTCTCTCTCTCTCTCTAC & 64 & 6 & 2 & 4 & 66.67 \\
3 & ISSR3 & CACACACACACAAG & 62 & 7 & 4 & 3 & 42.90 \\
4 & ISSR4 & CAGCACACACACACACA & 66 & 6 & 4 & 2 & 33.33 \\
5 & ISSR5 & GTGTGTGTGTGTCC & 79 & 10 & 4 & 6 & 60.00 \\
6 & ISSR6 & CTCTCTCTCTCTCTCTGC & 67 & 7 & 3 & 4 & 57.14 \\
7 & ISSR7 & GAGAGAGAGAGAGG & 73 & 8 & 4 & 4 & 50.00 \\
8 & ISSR8 & AGCACGAGCAGCAGCGG & 35 & 7 & 2 & 5 & 85.71 \\
9 & ISSR9 & CACACACACACACAAT & 67 & 8 & 5 & 3 & 37.50 \\
10 & ISSR10 & AGCACGAGCAGCAGCGT & 70 & 10 & 3 & 7 & 70.00 \\
11 & ISSR11 & GTGTGTGTGTGTGTTG & 43 & 5 & 3 & 2 & 40.60 \\
12 & ISSR12 & GTGTGTGTGTGTGTCT & 43 & 6 & 4 & 2 & 33.30 \\
13 & ISSR13 & GCTGAGAGAGAGAGAGA & 70 & 9 & 6 & 3 & 66.67 \\
\hline
\end{tabular}

TNA $=$ Total number of allele TNL $=$ Total number of loci, NML $=$ Number of monomorphic loci, $\mathrm{NPL}=$ Number of polymorphic loci, \% $\mathrm{P}=$ Percentage polymorphism

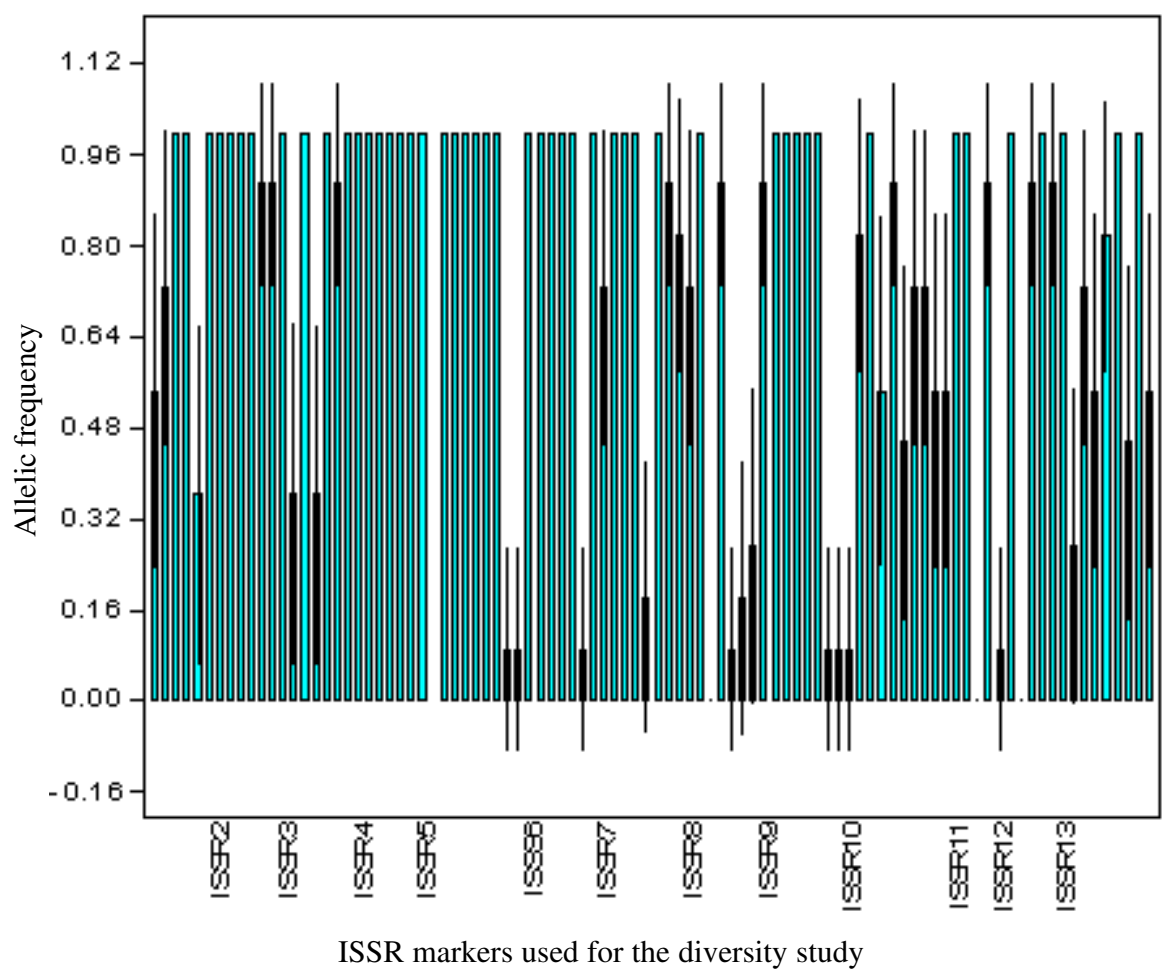

Figure 1. Allelic frequency amplification of the thirteen ISSR primers on eleven cultivated Nigerian acha genotypes. 
the frequency of amplification by each of the primer. Primers ISSR5 and ISSR 10 had highest allelic frequency of 79 and 70 , respectively followed by ISSR13; which occurred in nine loci but marked by 70 alleles. ISSR 8 had the least allelic frequency but interestingly had the highest polymorphism. The frequency of null allele was highest in primer ISSR11.

The Principal Coordinate (PCo) analysis of the bands and allelic fragments revealed that nine axes ( 9 markers) contributed significantly and accounted for $96.38 \%$ of the macrosatelite variations observed in the acha genotypes (Fig. $2)$. The first four most efficient markers; ISSR 8, 10, 2 and 13 cumulatively accounted for over $50 \%$ (59.24\%) of the variation. The PCo showed a genotype of D. exilis and D. iburua each in quadrants I. Quadrant II consisted of three exilis and one iburua members and the trend was similar for genotypes coordinate's quadrants III and IV; however, more genotypes (4) were placed in quadrant II (Fig. 2).

The genetic similarity among the eleven genotypes of acha (fonio millet) revealed average relationship. At similarity index of 0.68 , the dendrogram as defined by the thirteen ISSR markers revealed two major groups; A and B (Fig. 3). Group A consisted of two $D$. exilis (white acha) genotypes; Kebbi-1 and Kereep which were similar at 0.78 index. The second group (group B) had two subgroups (B1 and B2). The B1 had two clusters, whereas cluster B1(i) had two D. exilis members that were $84 \%$ similar; B1(ii) comprised of six genotypes of five $D$. iburua and a $D$. exilis, with the latter separated from the other five $D$. iburua members at 0.80 index scale. The other five members were more similar, but the closest genotypes of this cluster were Kebbi-2 and Bauchi. In contrast with the B1 sub-group, the B2 had only one genotype, Gwabi (D. iburua) a black fonio

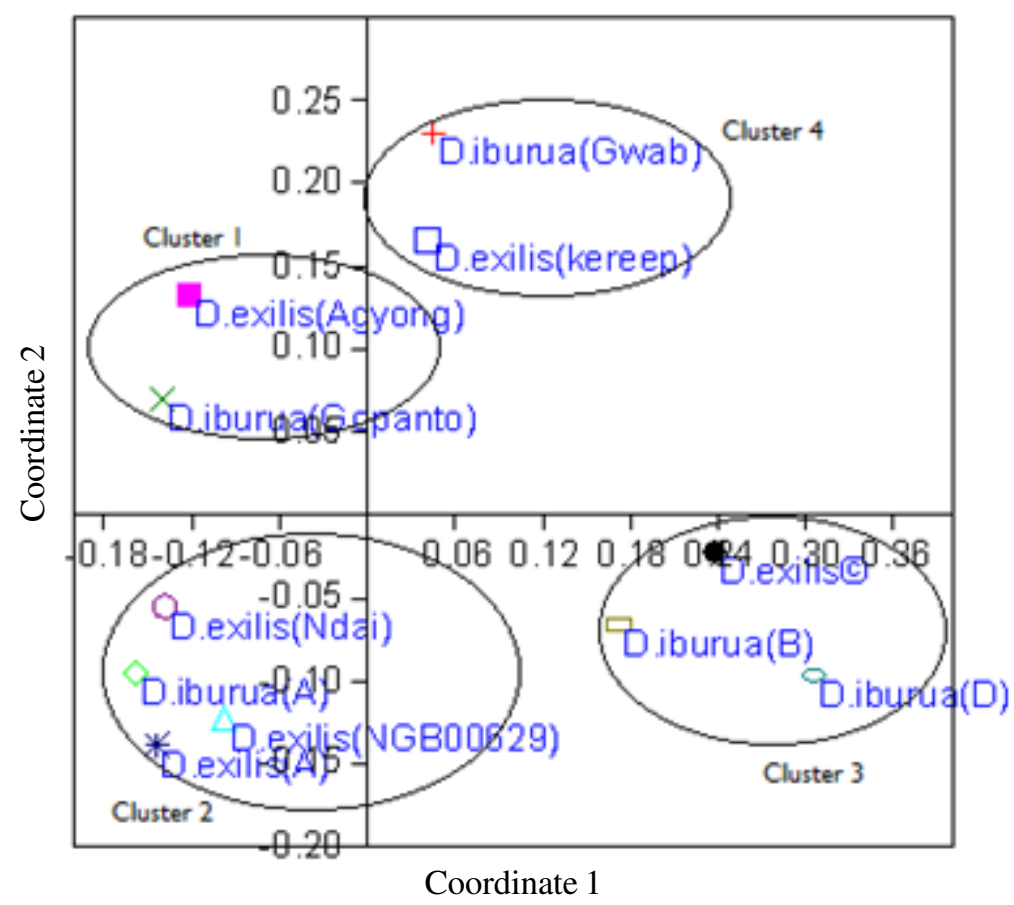

Figure 2. Principal coordinate (PCo) of loci and allelic fragments partitioning of the cultivated acha genotypes in Nigeria based on ISSR marker. 

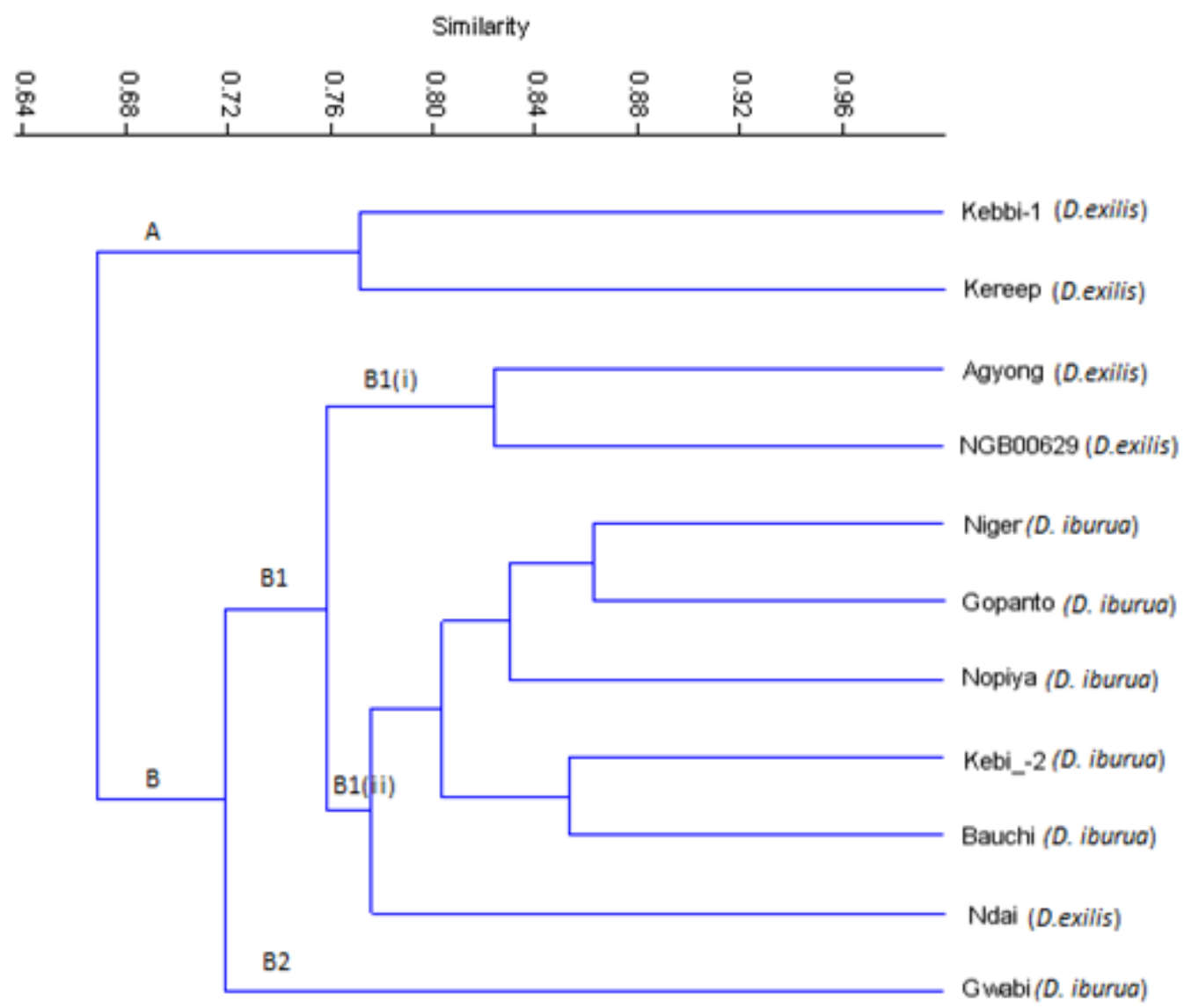

Figure 3. Dendrogram of genetic relationship among the genotypes of white (D. exilis) and black (D. iburua) acha cultivated in Nigeria.

TABLE 3. Principal coordinates of loci and allele fragments of acha genotypes based on ISSR markers

\begin{tabular}{lccc}
\hline Principal coordinates & \multicolumn{3}{c}{ Percentage of variation } \\
\cline { 2 - 4 } & Eigenvalue & Individual (\%) & Cumulative (\%) \\
\hline Axis 1 & 4.15 & 22.38 & 22.38 \\
Axis 2 & 2.81 & 15.18 & 37.56 \\
Axis 3 & 2.13 & 11.52 & 49.08 \\
Axis 4 & 1.88 & 10.16 & 59.24 \\
Axis 5 & 1.66 & 8.96 & 68.19 \\
Axis 6 & 1.51 & 8.17 & 76.36 \\
Axis 7 & 1.37 & 7.36 & 83.75 \\
Axis 8 & 1.22 & 6.59 & 90.34 \\
Axis 9 & 1.11 & 6.04 & 96.38 \\
\hline
\end{tabular}


millet which is distantly separated from the other D. iburua genotypes in group B.

\section{DISCUSSION}

Since amplification of DNA fragment by PCR depends on quality of the gDNA among other factors. A good DNA has ratio of $\mathrm{OD}_{260} / \mathrm{OD}_{280}$ between 1.8 and 2.0, values below and above this range signify protein and RNA contaminations, respectively. Meanwhile, the OD values obtained (1.5-1.72) in this study were good enough for amplification. To corroborate this, Scotti et al. (1999) remarked that DNA with low OD values could give a good PCR product, however, this statement is relative and did not distinctively elucidate the degree of impurity the technique could accommodate. In addition, DNA with OD values less than 1.5 was successfully amplified for SSR genetic analysis in accessions of yam (Otoo et al., 2009).

Inter- and intra-specific diversity assessment of germplasm is useful in conservation of genetic resources and prediction of combining ability of breeding materials (Animasaun et al., 2015). Fragment amplification by the ISSR primers revealed inter- and intra-genetic diversity among the genotypes of Digitaria exilis and D. iburua in Nigeria. This implies that the markers are effective for the genotypes partitioning and identification. The genotypes showed considerable heterologous amplification of the alleles, where about $46 \%$ were monomorphic and over $53 \%$ were polymorphic. This indicated that the ISSR markers are effective in revealing genetic variations in the genotypes. This is in agreement with earlier studies which demonstrated that microsatellite markers are effective in genotyping and fingerprinting of plant accessions (Ajibade et al., 2000; Animasaun et al., 2015).

A high number of alleles and polymorphism are important for correct estimation of genetic diversity of a germplasm. Since, microsatellite profiles are commonly interpreted in terms of allele phenotype, the degree of polymorphism correlates to diversity and effectiveness of the markers (Pfeiffer et al., 2011). Although a few of the markers had low allelic frequencies, low number of loci amplification and percentage polymorphism, most of the primers produced higher polymorphism. Significantly low numbers of alleles and gene diversity was recorded in cultivated pearl millet accessions compared with wild accessions using SSR markers (Oumar et al., 2008). However, Azevedo et al. (2012) reported high loci amplification and polymorphism in napier grass and millet accessions using microsatellite markers. The present study conform to latter findings as eight $(60 \%)$ of the primers produced polymorphism above $50 \%$.

The result of cluster analysis revealed that although, $D$. exilis are genetically dissimilar from the D. iburua, some degree of intraspecific diversity also existed. The genetic variation in these two species was also earlier reported (Hilu et al., 1997; AdoukonouSafgadja, 2010). Although authors summations were based on morphological and agronomical studies, the pattern of cluster obtained in this study further support existence of genetic variability among the genotypes. Separation of the genotypes into two major group at genetic similarity index of 0.66 , revealed that the genotypes were of two classes, (i) a class of homogenous species (D. exilis) and (ii) the other consisting of heterogeneous members (mixture of exilis and iburua). The genetic relationship that exits between Agyong, NGB00629 and Ndai, which are all exilis genotypes, but are clustered with the iburua suggested that they are genetically linked. More so, the species are members of the same genus, hence some degree of similarity would be expected, which they may have evolved from a common progenitor. The pattern of cluster in the present study concurred with genetic analysis of the Togo fonio accessions using random amplified polymorphic DNA (Hilu, 1995). 


\section{CONCLUSION}

Accurate assessment of genetic diversity is important in crop breeding and adequate genetic information would identify potential parental combinations to create segregating progenies with maximum genetic variability for further selection. Findings from the present study showed that ISSR markers are valuable asset for estimating genetic diversity. The polymorphism obtained indicate remarkable inter- and intra-specific variation among the available genotypes of acha in Nigeria. Occurrence of D. exilis and D. iburua together in a cluster revealed their relatedness and suggesting a common ancestor. It is, however, imperative that more genotypes and wild relatives from diverse sources be evaluated for diversity and phylogeny to provide broader genepool from where selection can be made for a breeding programme to improve the crop

\section{ACKNOWLEDGMENT}

The authors are grateful to the Acha Programme Coordinator, National Cereal Research Institute, Badeggi, Niger State, Nigeria for providing some of the acha genotypes used for the study.

\section{REFERENCES}

Adoukonou-Sagbadja, A.H. 2010. Genetic Characterization of traditional fonio millets (Digitaria exilis, D. iburua Stapf.) Landraces from West-Africa: Implications for conservation and breeding. Ph.D. thesis, Justus-Liebig University, Giessen, Germany. 107pp.

Adoukonou-Sagbadja, H., Dansi, A., Vodouhè, R. and Akpagana, K. 2006. Indigenous knowledge and traditional conservation of fonio millet (Digitaria exilis Stapf, Digitaria iburua Stapf) in Togo. Biodiversity and Conservation 15:23-29.

Ajibade, S.R., Weeden, N.F. and Michite, S. 2000. Inter simple sequence repeat analysis of genetic relationships in the genus Vigna Eupytical 111:47-55.

Animasaun, D. A., Morakinyo, J.A., Mustapha, O.T. and Krishnamurthy, R. 2015. Assessment of genetic diversity in accessions of pearl millet (Pennisetum glaucum) and napier grass (Pennisetum purpureum) using micro satellite (ISSR) markers. Iranian Journal of Genetics and Plant Breeding 4(1):25-35.

Azevedo, A.L., Costa, P.P., Machado, J.C., Machado, M.A., Pereira, A.V. and da Silava Ledo, F.J. 2012. Cross species amplification of Pennisetum glaucum Microsatellite markers in Pennisetum purpureum and genetic diversity of Napier grass accessions. Crop Science 52:17761785.

Clayton, W.D. and Renvoize, S.A. 1980. Genera Graminum, grasses of the world. Kew Bull Add Series XIII.

Dachi, S.N. and Gana, A.S. 2008. Adaptability and yield evaluation of some Acha (Digitaria exilis and Digitaria iburua Kippis Stapf) accessions at Kusogi - Bida, Niger State, Nigeria. African Journal of General Agriculture 4(2):73-77.

Haq, N. and Ogbe, F.D. 1995. Fonio (Digitaria exilis and Digitaria iburua): Cereals and pseudocereals, boundary row, Chapman \& Hall, London. pp. 2-6.

Hilu, K.W. 1995. Evolution of finger millet: evidence from random amplified polymorphic DNA. Genome 38:232-238.

Hilu, K.W., M'Ribu, K., Liang, H. and Mandelbaum, C. 1997. Fonio millets: Ethnobotany, genetic diversity and evolution. South African Journal Botany 63:185-190.

Maji, A.T., Dachi, S.N. and Yisa, J. 2003. Evaluation of Morphological variations within and between 10 Acha collections in NCRI accessions. NCRI Annual Report. pp. 90-94.

Morales-Payan, J.P., Ortiz, J.R., Cicero, J. and Taveras, F. 2002. Digitaria exilis as a crop in the Dominican Republic. pp. S1-S3. In: 
Supplement to trends in new crops and new use. Janick, J. and Whipkey, A. (Eds.). ASHS Press, Alexandria, Virginia (VA), USA.

Otoo, E., Akromah, R., Kolesnikova-Allen, M. and Asiedu, R. 2009. Delineation of pona complex of yam in Ghana using SSR markers. International Journal of Genetics and Molecular Biology 1(1):006-016.

Oumar, I., Mariac, C., Pham, J.L. and Vigouroux, Y. 2008. Phylogeny and origin of pearl millet (Pennisetum glaucum [L.] $\mathrm{R}$. Br) as revealed by microsatellite loci. Theoretical and Applied Genetics 117:489497.

Pfeiffer, T., Roschanski, A.M., PannellKorbecka, G. and Schnitter, M. 2011. Characterization of microsatellite loci and reliable genotyping in a polyploidy plant, Mercurialis perennis (Euphorbiaceae). Journal of Heredity 102: 479-488.

Portères, R. 1946. L'aire culturale du Digitaria iburua Stapf, céréale mineure de l'ouestAfricain. Agronomia Tropical 1: 589-592.

Portères, R. 1976. African Cereals: Eleucine, Fonio, Black Fonio, Teff, Brachiaria,
Paspalum, Pennisetum and African Rice. In: Origin of African plant domestication. Harlan, J.R., de Wet, J.M.J and Stemler, A.B.L. (Eds.). Mouton Publishers, The Hague. pp. 409-451.

Semagn, K., Bjørnstad, A. and Ndjiondjop, M.N. 2006. An overview of molecular marker methods for plants. African Journal of Biotechnology 5:2540-2568.

Scotti, I., Paglia, G., Magni, F. and Morgante. M. 1999. Microsatellite markers as a tool for detection of intra- and interpopulational genetic structure. In: Which DNA marker for which purpose? Final Compendium of the Research Project Development, Oprtimization and validation of molecular tools for assessment of biodiversity in forest trees in the European Union DGXII Biotechnology. Gillet, E. D. (Ed). FW IV Research Programme Molecular Tools for Biodiversity. http://webdoc.sub.gwdg.de/ ebook/1999/whichmarker/index.htm

Vietmeyer, N.D., Borlaugh, N.E., Axtell, J., Burton, G.W., Harlan. J.R. and Rachie, K.O. 1996. Fonio (Acha) Lost crop in Africa. BOSTID Publication. pp. 59 - 75. 